\title{
PRÁTICAS TRADUTÓRIAS NA ESPANHA: O TRABALHO DO TRADUTOR E SUAS FRONTEIRAS
}

\author{
Amanda Ramos Francisco ${ }^{1}$
}

RESUMO: This article intends to propose some of the main features that interfere with the translators' work. Some of these restrictions are the status of the source text, as well as that of the source and the target literatures. Another important factor that must be considered when studying translated texts is the patronage involved, that is, the goals of each translation must be taken into account. Similarly, the values of the receptor culture, which usually are also the translator's values, are important tools for the assessment of translation products. This article brings examples of different translation practices in Spain, such as that of the Church translators in the XII century, and that of the King translators in the 1200's, as well as those developed in the XVIII/XIX centuries. These periods are all considered by many scholars to be times of intense production of translations.

PALAVRAS-CHAVE: Patronagem. Status. Valores culturais. Práticas tradutórias.

\section{A TRADUÇÃO NA ESPANHA MEDIEVAL}

A tradução nunca é uma simples comunicação entre iguais, uma vez que a cultura que recebe o texto estrangeiro nunca o faz sem domesticá-lo, para usar o famoso termo proposto por Lawrence Venuti (1995). O tradutor encarregado atua também como um reprodutor de valores, de valores presentes em sua cultura, já que cada tradução representa um novo trabalho de interpretação realizado por um (às vezes mais de um) indivíduo que é mediado por sua própria cultura.

O presente artigo tem por objetivo realizar um estudo introdutório acerca das condições extraliterárias que envolveram a produção de traduções em diferentes épocas na Espanha. Os períodos abordados serão, por um lado, os séculos XII e XIII e, por outro, os séculos XVIII e XIX. A inclusão deste espaço de tempo mais longo, representado pelos anos de 1126 a 1287 e tomado aqui como um bloco em relação aos séculos XVIII e XIX, deve-se ao fato de que estas fases são tradicionalmente vistas como épocas de abundantes traduções na Espanha.

A fim de traçar o instigante panorama no qual se desenvolveram os trabalhos de tradução no século XIII na Espanha, é preciso retroceder ao século XII, até porque, apesar de muitos críticos olharem para este amplo período como uma só empresa, há algumas diferenças importantes que serão, ainda que de forma resumida, brevemente relacionadas. Nessa época, reconhecendo a insuficiência do desenvolvimento da ciência no mundo latino, alguns estudiosos ligados à Igreja Católica se encarregaram de traduzir diversas obras do árabe ou hebreu para o latim, a língua do clero e também o único veículo de transmissão de conhecimento nesta parte do Globo.

Assim, teve início uma grande empreitada que perdurou por quase todo o século e na qual a tradução tinha como principal função a inserção de novos conhecimentos no incipiente panorama cultural espanhol. Essa necessidade de enriquecimento através de obras estrangeiras, isto é, a busca por sabedoria do conhecimento que tal procedimento ofereceria, é também perceptível na abrangência do grupo de tradutores: a maioria era de estrangeiros que chegavam à Espanha na tentativa de aprofundar seus conhecimentos sobre determinadas matérias. Gerardo de Cremona, um dos mais profícuos tradutores, era italiano. Também havia ingleses (Roberto de Chester, Abelardo de Bath), eslavos (como Hermann el Dálmata), escoceses (como Miguel Scot) e alemães (como Hermann Alemán).

Este foi um dos motivos que fez com que os principais tradutores deste período não formassem um grupo coeso, visto que muitos deles passavam apenas algum tempo na Espanha e depois voltavam aos seus lugares de origem ou se instalavam, ainda, em outro país. Aliás, esta não é a única razão desta dispersão verificada, especialmente quando comparamos esta situação com a dos tradutores do século seguinte. Dessa maneira, os motivos que os desuniam podem ser variados, mas havia um grande elo de união entre estes homens: o seu compromisso com a Igreja, que, naquele momento, possuía um grande poder político.

\footnotetext{
${ }^{1}$ Amanda Ramos Francisco é doutoranda de Literatura Comparada/Estudos de Tradução no Instituto de Letras da Universidade federal do Rio Grande do Sul e orientanda da Dra. Sara Viola Rodrigues. Este trabalho foi realizado durante o estágio de doutorado realizado na Universitat de Barcelona (UB) em 2004.
} 
Portanto, foi através desses tradutores que se deu à ampliação do sistema cultural espanhol, que adicionou ao seu contexto muito da sabedoria árabe e grega. Isto ocorreu de forma indireta, já que é interessante notar que os latinos chegaram ao conhecimento de diversas obras de autores gregos através de traduções de estudiosos árabes, que, por sua vez, chegaram a estes livros e manuscritos em um período anterior, o que caracteriza as traduções desempenhadas durante o século XII como, em muitos dos exemplos, casos claros de indirect translation.

Os comentários inseridos nas obras traduzidas por homens ligados ao clero também dão uma idéia sobre uma das conseqüências da tradução indireta, isto é, a tradução de uma obra já traduzida. Uma das formas de manipulação textual explorada pelos tradutores é a inserção de comentários. No século XII, alguns tradutores escreviam prefácios ou prólogos nos quais ofereciam indicações relativas às modificações dos textos-fonte. É o que Hugo de Santalla faz no prefácio à sua tradução latina de um comentário árabe inserido em uma obra de al-Juwarizmî, por exemplo (D'ALVERNY, 1982, p.448).

Contudo, e aí se dá a relação com a tradução indireta, vários desses comentários já tinham sido inseridos pelos árabes nas traduções de textos gregos, pois os sábios árabes que traduziram os grandes textos da ciência e da filosofia gregas já haviam integrado, em suas produções, atualizações, observações e reflexões pessoais. Portanto, ao trabalharem com manuscritos que continham, por vezes, dadas características (digressões, acréscimos, omissões...) talvez sua tarefa tenha sido dificultada e ainda algumas dessas interferências podem ter servido como referência, como um modelo, já que várias destas considerações realizadas pelos tradutores árabes devem ter sido retraduzidas para o latim, no século XII, e mesmo para o romance, no século XIII, o que demonstra que a "leitura e produção" desenvolvidas pelos primeiros tradutores foi passada adiante através de traduções subsequientes.

O fato de várias versões do texto "original" provavelmente estarem presentes em outras traduções também leva ao questionamento sobre a "originalidade" do texto e mais, quando se leva em conta essa possibilidade, tais intervenções podem ser consideradas como estratégias de questionamento da autoridade retida por um determinado autor. Contudo, não parece ser sensato simplesmente culpar o tradutor por exercer "mal" seu ofício, pois a veiculação de valores é uma prática que se encontra inscrita nos procedimentos de escrita textual, entre os quais se encontra a tradução.

De maneira similar, abordagens com tendência marcadamente científicas, que pretendem ser objetivas e livres de valores específicos, também não parecem ser uma maneira adequada de avaliar a prática da tradução, uma vez que esta sempre envolve a questão dos valores, sejam eles os mesmos, ou totalmente divergentes, daqueles que foram implementados pelo escritor do texto-fonte.

Assim, no século XIII, por exemplo, um trabalho de criação tinha características bastante diversas daquelas nas quais pensamos ao ler um texto "original" hoje. Nessa época, uma obra de criação era um escrito baseado em materiais provenientes de "heranças recebidas" (LE GOFF, 1990, p.8). Assim, o novo "autor" era responsável por reestruturar o texto base, revivificando elementos (e, por consequiência, negligenciando outros). Um exemplo de homem que foi considerado mais um autor do que um tradutor, conforme a noção de autoria acima mencionada, foi Ishâq b. Sîd, um sábio judeu que participou dos trabalhos de tradução realizados durante o reinado de Alfonso $\mathrm{X}^{2}$. Entre as quatorze produções de Sîd somente três são traduções, todas as outras são composições, como a obra Tablas Alfonsies, provavelmente desenvolvida entre 1263 e 1272. Portanto, Ishâq b. Sîd foi, sobretudo, um autor, ainda que por isso se entenda que a ele cabia encontrar, agrupar e adaptar os materiais e não, pelo menos não por completo, criar as obras em questão (FOZ, 2000, p.74).

De forma similar, esta ampla noção de autoridade sobre o texto tornava legítimo que o monarca Alfonso X mandasse fazer, a partir de textos existentes, o "seu" texto, pois o livro que se fazia para o Rei de fato se transformava em um livro seu. Uma das notas encontradas na obra General Estoria ${ }^{3}$ é bastante significativa. A seguir está o último trecho da nota:

El Rey hace un libro no porque lo escriba con sus manos, sino porque determina sus contenidos, los corrige, los ordena, los arregla e indica cómo se deben hacer, y después los escribe quien él mande, por eso decimos que el Rey hace el libro. Es como cuando decimos que el Rey hace un palacio o una obra; no decimos que lo hizo con sus manos, sino que lo mandó hacer y dio las cosas que fueron necesarias para ello. Y quien esto cumple es quien hace la obra y eso solemos decir en él (SOLALINDE, 1915, p. 286).

Como neste período medieval as noções de autoria e de originalidade ainda não estavam consolidadas, o importante era incorporar o conhecimento aportado pelos chamados "infiéis". Os clérigos, seduzidos pelas possibilidades de expansão de seu saber, justificavam a tradução das obras pagãs como uma maneira de se apropriar do conhecimento estrangeiro e, de certa forma, purificá-lo, aniquilando então a sua fonte e tendo a certeza de que tal saber seria buscado e conquistado com o fim de favorecer a Igreja e de ampliar seu domínio. Em uma carta escrita pelo clérigo inglês Daniel de Morley e dirigida ao bispo de Norwich, este também tradutor descreve as suas angústias:

La pasión por el estudio me había expulsado de Inglaterra. Pasé un tiempo en París. Allí no vi más que salvajes instalados con una grave autoridad en sus asientos escolares (...). Su ignorancia les obligaba a una actitud de 
estatua, pero pretendían mostrar su sabiduría con su mismo silencio. En cuanto trataban de abrir la boca no escuchaba más que balbuceos de niños. (...) Como hoy en día Toledo es el lugar donde la enseñanza de los árabes, que consiste casi enteramente en las artes del quadrivium, se dispensa a las multitudes, también me di prisa por llegar allí e escuchar las lecciones de los más sabios filósofos del mundo. (...) vine a Inglaterra con una valiosa cantidad de libros. Me dijeron que en estas regiones la enseñanza de las artes liberales se desconocía, y que Aristóteles y Platón estaban condenados al más profundo olvido en beneficio de Tito y Seius. Fue grande mi dolor, (...) que nadie se conmueva si, al tratar de la creación del mundo, no invoco el testimonio de los Padres de la Iglesia, sino el de los filósofos paganos, pues, aunque éstos no figuren entre los fieles, algunas de sus palabras, desde el momento en que están llenas de fe, deben incorporarse a nuestra enseñanza. (...) Despojemos pues, conforme el mandato del Señor y con su ayuda, a los filósofos paganos de su sabiduría y de su elocuencia, despojemos a estos infieles de tal modo que nos enriquezcamos con sus despojos en la fidelidad (LE GOFF, 1985, p. 23-24).

Os acréscimos e as omissões realizados por este grupo de tradutores têm como um de seus principais propósitos a vontade de orientar a leitura do texto conforme a doutrina professada pela Igreja Católica. Eles viam o texto-fonte como um material básico do qual extrairiam sua própria leitura e comporiam sua própria versão. Portanto, a transliteração, o calco direto e a tradução intralinear estavam entre as técnicas de tradução mais empregadas à época.

Já no próximo século e com a subida ao poder daquele que seria conhecido como Rei Alfonso X, o Sábio, também a tradução teve um papel-chave no desenvolvimento das ciências. Contudo, o século XIII foi marcado pelo que André Lefevere chamaria de "patronagem não-diferenciada", isto é, aquela na qual os elementos que restringem o trabalho de tradução (status e elementos de base econômica e ideológica) se encontram na mesma instituição. É interessante destacar que, neste caso, essa intervenção do "patrão" parece ser definitiva e muito marcada, caracterizando um caso bastante peculiar: o Rei Alfonso X participava de maneira ativa nas empreitadas de tradução, pois, além de escolher obras, o monarca ainda escreveu prólogos para algumas delas e até participou de, pelo menos, uma revisão de trabalho ${ }^{4}$.

Talvez essa participação tão dinâmica exercida pelo Rei seja explicada por razões políticas e culturais. A necessidade de aquisição de conhecimento e de amadurecimento do mundo latino, claramente percebida no século anterior, persistia e, com ela, a necessidade da tradução como a forma mais rápida de "anexar" saberes. No entanto, no século XIII há a inserção do romance, a língua oral, como língua de chegada de textos escritos em árabe, grego, hebreu e latim. Talvez a política do Rei de usar o romance como língua escrita demonstrasse seu desejo de criar divisas territoriais, afastando-se da Igreja e, além disso, de moldar um patrimônio lingüístico em língua "própria".

É interessante notar o papel decisivo que a prática tradutória teve na própria formação do vernáculo na Espanha. Como o romance era considerado uma língua vulgar, usada apenas para a comunicação oral, a empreitada de render textos nesta "nova" linguagem representou, sem dúvida, um grande desafio para os colaboradores do Rei Alfonso X. A questão lingüística é um ponto central nos trabalhos realizados no século XIII, pois foi preciso um esforço lexicográfico considerável para admitir em romance os conhecimentos oferecidos pelos textos árabes.

Durante o reinado de Alfonso X foi preciso desenvolver toda a língua escrita. Foi também necessário criar diversos termos especializados que explicassem as idéias transmitidas pelos vocábulos empregados nos textos árabes. Dessa forma, diversas palavras foram cunhadas e incorporadas ao romance através das traduções. De fato, o Rei encontrou na prática tradutória uma importante maneira de se distanciar do poder eclesiástico através da criação de uma cultura nacional, que também passava pelo desenvolvimento de uma língua vernácula como transmissora de saberes, e não mais o latim, que por tempos figurou como o único instrumento de veiculação de poder.

O monarca tinha o propósito de aumentar seu poder através do enriquecimento e fomento de símbolos nacionais/nacionalistas, a fim de que sua cultura se diferenciasse do mundo latino e da Igreja Católica. Portanto, não se pode alegar que Alfonso X estivesse "esquecido" da política e pensasse somente nas artes, pois o que ele intencionava era justamente utilizar as artes a fim de fortalecer seu domínio político. A este respeito, o comentário de Clara Foz é útil:

Sin embargo, la voluntad del soberano de producir unos textos claros y fáciles de comprender no se debería identificar con una política de "pureza lingüística". (...) algunos vocablos de origen árabe reemplazan a otros heredados del latín, un hecho que muestra una voluntad de enriquecer y ampliar la lengua vulgar y, al mismo tiempo, de afirmar una cierta particularidad española y separarse de un mundo donde el latín reina como amo. Si el soberano promueve el uso de un "castellano derecho", lo hace con el objetivo declarado de hacer valer la legitimidad y la pertinencia de la lengua vulgar (...) contrarrestar la supremacía del latín y, con ello, la supremacía de aquellos para los cuales esta lengua existe, los representantes de la Iglesia. (...) ¿ Cómo no ver, en las posiciones lingüísticas adoptadas por Alfonso X (...) una estrategia, del todo inédito en esta época, de puesta en entredicho de la validez de un modelo latino universal, y por otro, de una política que, lejos de ser la de un soberano "demasiado docto" para interesarse por los asuntos de Estado (FOZ, 2000, p.103). 
De acordo com a política empregada pelo Rei, tornava-se desejável que as produções em romance fossem acessíveis, pois este monarca desejava ser lembrado como aquele que contribuiu com um legado de instrução ao seu país. Dessa forma, mesmo que os assuntos traduzidos oferecessem um certo grau de especialização (astronomia e astrologia, por exemplo), havia um esforço por tornar o texto traduzido lingüisticamente fluido, além de um trabalho que intentava incluir, sempre que se julgasse necessário, explicações acerca dos termos técnicos empregados. Quando a adoção de vocábulos em árabe se tornava imprescindível, os tradutores mostravam uma tendência de acrescentar comentários sobre as origens etimológicas de dados termos, tentando oferecer complementações e explicações científicas. Esta estratégia é tão marcada devido à política de tradução almejada pelo Rei e compartilhada, claro, por seus colaboradores e súditos.

Neste ponto, a prática de tradução desenvolvida no século XIII se apresenta de forma diferente daquela utilizada no século XII, já que no segundo período as traduções se destinavam a um público reduzido, que queria conhecer as ciências árabes e gregas, sendo que muitas vezes os próprios tradutores haviam decidido realizar este trabalho a fim de aprender mais sobre seu próprio ofício (no caso de profissionais que traduziam obras árabes com temas relacionados a sua profissão). Quando estes tradutores se deparavam com algum termo técnico eles adotavam, em geral, a solução mais imediata: a transliteração, como no caso do vocábulo suda, que denomina dor de cabeça e que Gerardo Cremona, um dos tradutores mais conhecidos da Idade Média, verteu para o latim como soda (BEAUJOUAN, 1968, p.146).

No século XII, o fato de pertencer, de algum modo, à Igreja importava mais do que ser versado nos temas traduzidos. Contudo, ainda assim, pode-se detectar uma certa especialização nesses colaboradores: Abraham bar Hiyya, tradutor judeu nascido en al-Andalus e que atuou em Barcelona, se dedicou, sobretudo, às matemáticas; já Domingo Gundisalvi, um dos tradutores de Avicena, trabalhou com vários textos sobre filosofia. Este fato, no entanto, não quer dizer que os trabalhos fossem divididos de acordo com a especialização do tradutor, mas como os alvos das traduções nesta fase eram os textos específicos de variadas áreas do conhecimento, é natural que os próprios tradutores se encarregassem de escolher as obras que desejavam desenvolver.

Contudo, durante o período de traduções sob o comando do Rei Alfonso X, duas condições tornam esta empresa tradutória diferenciada: a primeira se refere à gama de campos do saber contemplados pela tradução: como o Rei era quem escolhia as obras para serem traduzidas, o número de áreas era reduzido. Alfonso X contava com estudiosos que tratavam de compilar materiais e revisá-los, a fim de relatar sua relevância para o monarca. O próximo passo era a tradução; a maioria dos textos traduzidos neste período trata sobre astrologia e astronomia, os assuntos favoritos do Rei, até porque na Idade Média era comum que os poderosos consultassem previsões astrológicas para tomar decisões políticas mais acertadas.

Assim, nada mais lógico do que o desejo de ampliar os conhecimentos nesta área através da tradução de manuscritos de grandes mestres. A maneira de traduzir sob o domínio da Igreja e do monarca também era diferente: no século XII nem todos tradutores sabiam árabe. Devido a este panorama, era preciso realizar um trabalho com um arabista, que lia o texto em voz alta, e de um latinista, que dava sua versão em latim. Essa colaboração, entretanto, não era reconhecida, já que quase sempre somente o latinista era considerado como o tradutor daquela obra.

No reinado de Alfonso X, ao contrário, os livros traduzidos eram considerados propriedade do Rei, mas a participação de cada indivíduo era especificada. Ademais, havia uma certa divisão permanente do trabalho, que contemplava as etapas de avaliação da tradução, revisão e correção. Havia, por assim dizer, uma equipe editorial que se encarregava de dar um "acabamento" à obra traduzida e que contava, ainda, com compiladores, copistas e iluminadores.

\section{UM PANORAMA DAS TRADUÇÕES REALIZADAS NOS SÉCULOS XVIII E XIX}

Alguns autores definem a literatura espanhola, neste período, como um sistema literário impregnado por uma forma e uma poética não-próprias (a França, nesta época, servia como principal modelo), pois muitos críticos afirmam que nesta fase da vida literária espanhola havia uma preferência pelo importado. Dessa maneira, este sistema literário contava com um público leitor que havia desenvolvido um gosto por obras de autores estrangeiros. Este era, assim, um ambiente muito favorável à proliferação de traduções. Havia até algumas pequenas e médias editoras (funcionando em conexão estreita com a imprensa), que não eram especializadas em tradução, uma vez que este ofício ainda se confundia muito com a própria criação autoral e era uma ocupação, na maior parte das vezes, desenvolvida por autores que se aventuravam na transladação de textos de seus autores estrangeiros favoritos.

As traduções eram principalmente realizadas por autores ou intelectuais que se interessavam por uma determinada obra ou autor(es) e, com frequiência, essas produções eram publicadas em periódicos. Eugenio Ochoa, por exemplo, traduziu algumas obras de George Sand do francês para o espanhol. Uma verificação cuidadosa da 
produção de traduções durante este século apontaria uma grande quantidade de obras traduzidas do francês, idioma que, em termos de frequiência de traduções na Espanha, era seguido de longe por idiomas como inglês e italiano ${ }^{5}$.

Contudo, mesmo que este apego à literatura alheia à primeira vista possa parecer uma forma de simples absorção de valores de culturas estrangeiras (especificamente a francesa, neste caso), grande parte das traduções realizadas passava, na verdade, por uma série de adaptações que se devem a alguns distintos fatores. Em primeiro lugar, cabe aqui ressaltar o papel de "formadores" de opinião e de construtores de cultura desempenhado pelos intelectuais que produziram neste período da vida sociocultural espanhola. Ainda não havia a educação contínua e específica de tradutores, sendo que as pessoas que desempenhavam este trabalho também poderiam lecionar em escolas, exercer profissões liberais, atuar na imprensa etc.

A própria escolha das obras a serem traduzidas já demonstrava uma certa atitude em relação à tradução destes textos. Muitos tradutores elegiam o texto de acordo com o tema abordado, muitas vezes preferindo aqueles de aceitação garantida entre o público espanhol. Isto é especialmente verdadeiro quando se considera a tradução para teatro, não apenas porque o seu estudo é facilitado pela grande quantidade de peças traduzidas e apresentadas na época, como também pelas necessárias (e "confessionais") adaptações sofridas pelo texto ao cruzar fronteiras geográficas, lingüísticas, ideológicas, culturais, enfim, para que esta produção atingisse êxito de público e/ou crítica.

Muitas obras, por exemplo, eram traduzidas de forma a não ferir a moral vigente naquela sociedade, especialmente porque o sucesso de venda de um romance publicado ou de uma peça encenada dependia das críticas publicadas em periódicos, que faziam uma espécie de triagem sobre a recepção desse tipo de literatura. Assim, muitos tradutores incorporavam ou cortavam elementos do texto estrangeiros pretendidamente a fim de facilitar a leitura. Alguns exemplos de domesticação do texto traduzido podem ser verificados no corte de trechos que continham referências de fundo cultural.

Um caso ilustrativo é o oferecido pelo tradutor Vitor Vallaguer. Em 1848, durante uma estada em Madri, traduziu uma das obras da autora George Sand, Primadona. Neste texto, o tradutor opta pela adaptação da obra ao gosto do público espanhol. Ele adiciona alguns trechos, ou mesmo parágrafos inteiros, a fim de explicar determinadas passagens que ele considera pouco claras. O tradutor omite algumas partes que julga menos românticas ou que contenham problemas "políticos" (como a associação das mulheres à Igreja, por exemplo). Além disso, há também a adaptação de referências culturais. Sand explora a imagem de D. Juan, personagem de uma ópera francesa e com conotações para este público bastante determinadas e talvez diferentes para o público espanhol. O tradutor apaga esta passagem, que poderia não soar tão representativa para o público receptor.

Havia muitos casos nos quais a ideologia aportada pelo texto estrangeiro era inaceitável para o público-alvo destas traduções, o que fazia com que o papel dos tradutores também fosse o de revisar e "filtrar" várias passagens que pudessem bloquear a distribuição daquele novo texto na cultura receptora. A própria George Sand, que escrevia com pseudônimo para conseguir publicar, defendia teses muitos "feministas" e "avançadas" para a época, o que redundava na adição de notas moralistas acerca de alguns trechos, além de omissões, adaptações, entre outros adereços.

Problemas de ordem ideológica também podem ser abordados através do estudo da tradução. $\mathrm{O}$ texto Feudalismo y Democracia é um exemplo. De autoria do Marquês de Riscal, este escrito foi assinado pelo tradutor, ou seja, o autor "se esconde" atrás do tradutor, quiçá uma figura menos visada no seu círculo social. O tradutor Lucien Lui Lande fazia parte da equipe editorial da Revue de Deux Monde, o que também facilitou a publicação deste texto que era, falsamente, seu. Aliás, diversos tradutores, por diferentes razões daquelas que moveram o tradutor Lande a assinar um texto alheio, utilizavam a fama de outros autores para veicular suas próprias idéias, seja através da assinatura de obras que não eram suas, seja através da reescritura na tradução, ou mesmo através de plágios ou de obras fortemente inspiradas em textos estrangeiros.

O escritor de fábulas espanhol Félix Maria de Samaniego (1745-1801), na obra El Jardín de Venus, imita vários contos contidos em Cent Nouvelles Nouvelles. É até possível, segundo Maria Rosário Ozaeta, estabelecer uma lista de relatos inspirados em contos franceses: assim, "El voto de los benitos" se remete a "L'abbesse guérie", "La procuradora y el escribiente" é copiado de "La procureuse passe la raye", "El panadizo" é um texto paralelo ao "Le doigt du moine guéri" e assim por diante.

Samaniego, ao iniciar sua "carreira" de fabulista, desejou reunir uma pequena biblioteca de escritores eróticos a fim de munir-se de argumentos e, ao mesmo tempo, aprender sobre as técnicas de narração. Jean de la Fontaine foi o principal modelo para este escritor. No prólogo de suas Fábulas, Samaniego reflete sobre suas estratégias de adaptação das fontes que emprega. Depois de ler e comparar os textos que lhe servem de modelo, ele decide seguir seus próprios critérios:

Me resolví a escribir (...) entregándome con libertad a mi genio, no sólo en el estilo y gusto de la narración, sino aun en el variar rara vez algún tanto, ya del argumento, ya de la aplicación de la moralidad, quitando, añadiendo o 
mudando alguna cosa, que sin tocar el cuerpo principal del apólogo, contribuya a darle cierto aire de novedad y gracia (OZAETA, 1999, p.313).

Muitos críticos que se dedicam ao estudo da literatura traduzida na Espanha afirmam que uma prática corrente era a adaptação das obras estrangeiras aos padrões da literatura espanhola. Havia uma espécie de nacionalização dos textos. Francisco Lafarga (1999), por exemplo, argumenta que este procedimento adotado pelos tradutores, que incluía a supressão e a adição de elementos textuais, se deve à noção de prática tradutória herdada da França ${ }^{6}$.

Esta afirmação se torna ainda mais veemente quando se observa que muitas obras de literatura alemã ou inglesa, para formular um exemplo, chegavam ao sistema literário espanhol a partir de traduções francesas, caracterizando casos conhecidos como indirect translations. Muitas vezes a versão espanhola não era criada diretamente dos textos-fonte, mas partia da versão francesa, cujos tradutores, por sua vez, já haviam desenvolvido uma reescritura restritiva e incluído ou excluído partes do discurso. O "novo texto" produzido durante sua versão francesa, assim, foi incorporado por traduções subseqüentes.

Não obstante, ao chegarem à Espanha esses textos também foram adaptados e moldados à poética desenvolvida em textos nacionais. Há muitos exemplos de tradutores que mudaram até mesmo o enredo de diversas obras. Esta discussão é especialmente pertinente no que se refere à análise de peças teatrais traduzidas. O estudo da recepção em teatro envolve, com certeza, os processos de representação de dado texto e seu êxito junto ao público. Dessa forma, para atender às exigências de patrocinadores em relação à venda de ingressos, era necessário que tanto a temática explorada quanto a linguagem utilizada estivessem de acordo com determinadas expectativas do público. No entanto, esta exigência "editorial" pode ser igualmente verificada em outras formas literárias.

Os prólogos a edições traduzidas, para citar um grupo de casos, em geral constituem uma rica fonte de análise das práticas tradutórias adotadas (fazendo um contraste com as que foram rechaçadas) em distintas épocas. Menedéz Pelayo, na primeira edição de sua tradução de Horácio, lançada em 1887, desenvolve um prólogo que dá conta da recepção do autor grego na literatura espanhola, que incluía um estudo das influências exercidas por Horácio em autores espanhóis, cotejos de traduções de suas obras, considerações de plágios, além de críticas a traduções anteriormente realizadas. Em caso de tradução de prólogos existentes nas versões "originais" do texto, pode-se ainda detectar a prática de adaptar alusões a outros textos, isto é, os tradutores buscavam no acervo "nacional" referências a obras e autores espanhóis, dispensando as alusões empregadas pelo autor do texto estrangeiro, domesticando o texto na tentativa de torná-lo um texto "genuinamente" espanhol.

As notas de pé de página de obras traduzidas para o espanhol também são reveladoras de uma literatura que dependia ainda da importação, mas cuja cultura possuía sérias restrições morais em relação à admissão de idéias e enredos contidos em muitos dos textos selecionados para tradução. Assim, Eugenio Ochoa, em uma tradução de Valentine, de George Sand, inclui em seu texto traduzido notas de cunho moralista, nas quais ele rebate algumas das crenças e teses defendidas pela autora. Esta produção também incluiu ilustrações que guardavam respeito à moral presente naquela sociedade, mostrando o papel da edição da obra, ou seja, provando que a adaptação de uma obra estrangeira extrapola as mudanças no âmbito do próprio texto escrito pelo autor.

Dessa forma, para que os textos traduzidos se adequassem à ideologia e poética do sistema literário espanhol, diferentes formas de reescritura foram colocadas em prática pelos tradutores espanhóis dos séculos XVII e XIX. Personagens secundários eram transformados em figuras centrais da trama ou vice-versa, algumas partes do enredo original eram parcial ou totalmente subvertidas, havia a inclusão de explicações, omissão de passagens, em especial de trechos que contivessem alusões à cultura do texto-fonte, ou nos quais existisse algum elemento que pudesse chocar o leitor, dificultasse sua compreensão ou mesmo atrapalhasse a venda de exemplares da nova obra.

Conseqüentemente, a fama dos autores estrangeiros deve muito (seja qual for o julgamento dos "resultados") ao trabalho de reescritura dos tradutores e parece correto dizer que nenhum trabalho de análise da recepção de autores franceses, alemães ou ingleses na Espanha do século XVIII ou XIX - e de todas as outras épocas e culturas - pode evitar o estudo do desenvolvimento das traduções desses autores, da mesma maneira que não deve esquecer o papel das restrições de fundo moral, ideológico ou cultural às quais estavam sujeitos os tradutores dessas obras e cujo "peso" certamente afetou o seu trabalho.

A tradução, tanto na época medieval quanto séculos mais tarde, continuou sendo um ofício que envolvia a reprodução ou a inserção de valores, que são manifestados através dos trabalhos de reescritura desempenhados por tradutores, editores e "patrões" atrelados às expectativas de venda etc. Por isso, a questão do poder está entranhada na relação entre textos-fonte e textos-alvo. Através da análise que se faz acerca da escolha do texto estrangeiro a ser traduzido e do tradutor, assim como de quem encomendou a tradução, a que público esta obra se dirige, além das adaptações que este texto sofre durante o trabalho de tradução, é possível perceber também que usos políticos este trabalho teve, que valores culturais rechaçou e quais vinculou, que status aquele texto em particular tem na sua própria cultura e na literatura receptora e que relação os dois sistemas literários envolvidos mantêm. 
Portanto, mesmo ao compararmos épocas tão distintas, vemos que as condições de produção tradutória envolvem quase sempre os mesmos tipos de restrições e mesmas variáveis. Os tradutores trabalham para alguém, como no caso dos súditos de Alfonso X, dos clérigos e a Igreja no século XII e dos escritores-tradutores (secs. XVIII-XIX) que estavam veiculados de alguma forma à elite cultural da época e precisavam estar conscientes de seu papel como revisores das idéias aportadas por textos estrangeiros.

Ao lidar com um texto estrangeiro e ter que reescrevê-lo em outra língua, que pertence a outro sistema literário regido por diferentes normas e distintos valores culturais, o tradutor precisa domesticar o texto em menor ou maior nível (dependendo das restrições), a fim de que ele seja fluentemente interpretado pelo público receptor. Aliás, esta domesticação não tem que ser intencional, pois, sendo um leitor, o tradutor também realiza a interpretação deste texto que lhe é estranho, de acordo com suas possibilidades, o que se reflete no texto produzido.

Para Schleiermacher, havia dois tipos de tradução: aquela na qual o tradutor leva o leitor até a língua e, implicitamente, até a cultura-fonte do autor e aquela em que o autor é levado ao leitor estrangeiro. Muitos estudiosos afirmaram preferir a primeira forma, como uma tentativa de não desnaturalizar ou manipular a obra "original". Entretanto, esta perspectiva não leva em conta a questão do poder envolvido nas práticas tradutórias. A chamada tradução etnocêntrica, na qual o autor é levado até o leitor, sempre existiu, como pode ser verificado após uma análise das traduções realizadas em quaisquer dos períodos até aqui mencionados. As questões do poder, da patronagem e de valores explicam porque um sistema literário com status menor utiliza a primeira forma de tradução descrita por Schleiermacher. Contudo, uma cultura como a dos Estados Unidos (ou como foi a da França na época das belles infidèles), por exemplo, tradicionalmente não produz traduções deste tipo.

\section{PRÁTICAS DE TRADUÇÃO}

Alguns críticos de traduções, adotando a posição simplista de busca por erros e inconsistências em textos transladados a culturas estranhas, parecem ignorar o fato de que estas inconsistências, omissões e adaptações são, de maneira geral, justamente as passagens que mais deram trabalho aos tradutores, ou seja, que não se trata sempre de erros por falta de atenção ou desconhecimento lingüístico (ainda que eles possam ocorrer, como, de fato, sempre ocorrem), mas sim de mudanças mais ou menos conscientes que serão reproduzidas naquele texto que será incluído nesta nova cultura. Tais transformações são consideradas como "necessárias" para que o texto obtenha sucesso de venda junto ao público leitor, ou para que seja aceito como obra canônica dentro daquela literatura.

É claro que um estudioso pode criticar práticas tradutórias empregadas, mas é preciso lembrar que estas críticas não devem ser ingênuas, com base na simples contagem de imprecisões do texto produzido. Muitas dessas inconsistências, especialmente as que não se referem exatamente a erros resultantes de um fraco domínio da estrutura gramatical do texto, têm origem em restrições sofridas também por estes participantes do sistema literário, até porque, se não fosse assim, mudanças no enredo, inclusão de notas moralistas e a domesticação dos textos estrangeiros seriam encontradas em apenas alguns tradutores (os "maus tradutores") e não de forma generalizada, como parece ser o caso em diferentes literaturas e épocas.

Isso se torna ainda mais claro se considerarmos que em diversos casos os tradutores mais requisitados eram justamente aqueles que mais produziam "inconsistências", o que nos leva a crer que este profissional era considerado muito competente, justamente porque conseguia atender a estas necessidades de reescritura da cultura receptora (desde o ponto de vista de quem pagava pela tradução, pois o presente texto não tem como objetivo a defesa da domesticação de textos estrangeiros através das omissões, adaptações, adições, desreferencializações, prólogos, notas, etc.). Contudo, é inegável que o estudo de traduções explica muito sobre o panorama cultural e sobre as relações extraliterárias envolvidas no processo tradutório.

A propósito do grau de consciência dos tradutores sobre os motivos das suas intervenções no texto estrangeiro, as escolhas dos tradutores nem sempre são conscientes (talvez não o sejam na maior parte dos casos). No entanto, elas parecem ser guiadas por um desejo de tornar o texto mais legível, mesmo que suas decisões discursivas possam acabar criando identidades subordinadas. Os tradutores, e mesmo muitas vezes a própria indústria editorial que contrata a tradução, estão inconscientes sobre a amplitude das práticas tradicionais e suas consequiências ou sobre os interesses a que tais políticas de produção servirão.

Dessa forma, é relevante considerar que a tradução envolve duas (ou mais) culturas. Este é um processo intercultural no qual o tradutor revisa o centro e a periferia de pelo menos duas culturas distintas (as culturas "fonte" e "alvo"). Lawrence Venuti (1998) argumenta que, a partir desta autoridade que o tradutor possui ao reescrever textos de outra cultura, podem ocorrer alguns casos de repressão das características peculiares de um autor. Ao realizar uma tradução que domestica o texto estrangeiro, ao desejar reescrever o texto de acordo com seus próprios 
padrões literários, muitas vezes o tradutor reprime um autor que introduziu inovações mesmo em seu próprio sistema literário.

Para ilustrar esta idéia, Venuti dá o exemplo de um dos tradutores de Jorge Luís Borges nos Estados Unidos, Norman Thomas di Giovanni, cujo trabalho de tradução e edição revisava agressivamente o texto em espanhol a fim de aumentar sua acessibilidade para o público-leitor norte-americano: "It's like cleaning a painting: you could see the bright color and the sharp outlines underneath where you couldn't see before" (VENUTI, 1998). O caso é que talvez o autor não quisesse que nenhum leitor, argentino ou de qualquer outra nacionalidade, recebesse o texto com suas cores tão "brilhantes" assim. No entanto, o estudioso argumenta que as traduções sempre envolvem domesticação, isto é, a tradução é um trabalho de interpretação e os tradutores são indivíduos mediados por dados valores culturais.

Portanto, aqui é possível estabelecer uma breve discussão acerca do conceito criado por Peter Newmark (1981): undertranslation ou infratradução. Segundo o estudioso, a infratradução é a deformação profissional do tradutor, algo que sempre ocorre, mesmo que seja em sentido oposto (overtranslation). Este procedimento resulta da forte tendência a uniformizar, a minimizar as seqüências da língua estrangeira. Esta noção tem a ver com a percepção de Gideon Toury sobre a redução da pluralidade lingüística no texto traduzido, ou seja, os tradutores acabam por trocar o específico (vários segmentos lingüísticos matizados) pelo mais geral, oferecendo para tais segmentos uma única opção.

No entanto, esta uniformização talvez não se dê apenas no âmbito lingüístico ou, com outras palavras, talvez a uniformização linguística não reflita apenas uma falta de "conhecimento" por parte do tradutor (que conhece aquela segunda língua em um certo nível, mas não é bilíngüe), mas também implique mudanças implementadas que se refiram à aceitabilidade do texto em questão na cultura nacional (cultura receptora).

A apreensão do significado do texto a ser traduzido sempre foi um desafio colocado aos tradutores, ainda que o que esta tarefa envolve tenha sofrido mudanças devido a outros desenvolvimentos em diversas áreas, principalmente nos campos da lingüística e da filosofia. Idéias sobre a "verdade" sob perspectivas como a platônica, que crê na existência de coisas eternas cujo significado puro seria atingido através das palavras, ou a positivista, que sustenta que poderíamos determinar o significado das palavras, pois elas simplesmente refletiam o que as coisas eram, foram mudando através da inclusão de novos aportes. Como conseqüência, houve um período de crise para as teorias sobre o significado, que teve seu ponto de origem na consideração da cultura como construtora da linguagem e como ferramenta para compreender seu uso.

No que se refere ao âmbito filosófico, houve um amplo movimento pós-positivista, que começou a questionar conceitos como o de língua pura, o que levou ao desenvolvimento de novas teorias em diversas áreas do conhecimento humano. Em relação ao estudo da linguagem, algumas escolas podem ser representativas de profundas inversões na definição de como a linguagem é apreendida e utilizada. A escola funcionalista, por exemplo, engloba algumas abordagens responsáveis por uma nova conceitualização acerca do trabalho do tradutor.

Nesta fase introdutória dos Estudos de Tradução, alguns exemplos de nomes de teóricos da tradução que são pós-positivistas e que estabeleceram uma nova forma para se pensar sobre este fenômeno foram W. Catford, que usou conhecimentos sobre a lingüística para subverter a abordagem positivista na tradução, e E. Nida, que criou uma noção de interface entre linguagem e função. Estes e outros teóricos têm sua importância no desenvolvimento do pensamento crítico sobre a produção de traduções, ainda que algumas de suas posições nos pareçam hoje desacreditadas. Nida, por exemplo, estava convencido de que os tradutores poderiam transpor o mesmo significado que um determinado texto teve na cultura-fonte para a cultura receptora, baseado em noções sobre equivalência que não dão aos valores culturais particulares a devida importância.

Entretanto, estas abordagens que surgiram a partir da década de 50 e 60 abriram caminho para novas abordagens que incluíram o papel da ideologia na cultura e, conseqüentemente, no uso da linguagem. A sociolingüística contribui para estes estudos quando afirma que para entender a linguagem a lingüística não é suficiente. Assim, novas perguntas sobre a prática tradutória estão ainda estão sendo amplamente discutidas: por exemplo, quando um texto é traduzido, será possível desembaraçar a idéia sobre o efeito no leitor da língua-fonte da ideologia do tradutor, da literatura e da própria cultura receptoras? Hoje sabe-se, através de vários estudos demonstrativos e comparativos, que diferentes processos de tradução podem levar a produtos de tradução muito distintos.

Em relação à função que o texto desempenha em uma cultura, sabe-se que esta função pode ser variante mesmo dentro de um mesmo grupo, com identidades culturais semelhantes. Assim, não há sentido em exigir que o tradutor "enxergue" todas as funções que uma obra tende a conter. Além disso, não é fácil determinar tais funções, uma vez que elas apresentam a tendência de mudar quando atravessam fronteiras e também de acordo com a época de sua leitura e com o status do escritor, da literatura etc. 
A fim de determinar o significado de um texto, é preciso considerar uma série de áreas e itens que envolvem a escritura, revisão, produção, edição, tradução e distribuição (nas culturas fonte e receptora) de um texto. Alguns dos itens mais relevantes em relação à discussão apresentada até aqui são a própria apresentação do livro, ou seja, a qualidade da impressão, a editora, as ilustrações, a grafologia, entre outras. Além disso, é positivo considerar o público-alvo desta produção (como, no caso de Alfonso X e sua corte), o acesso ao texto ou a sua exclusividade. No caso das traduções realizadas no século XII, de fato, os conhecimentos aportados por estes textos eram destinados a um grupo restrito. Isso fica demonstrado pela própria língua de chegada, o latim, que já restringia de forma considerável o público leitor do texto traduzido.

Os contextos social e histórico também têm um papel muito importante na consideração das traduções em uma cultura, assim como o lugar e a época de sua publicação. No caso da cena literária espanhola do século XVIII ou XIX, é preciso levar em conta também questões como costumes e elementos que assinalam hábitos de um grupo. O status das línguas e das literaturas envolvidas, da mesma forma, precisa ser avaliado quando se trata de textos literários. Os costumes de cada sociedade, a identidade do autor do texto, que neste caso não se aplica aos textos árabes traduzidos na Idade Média, além das tradições literárias de cada grupo, devem ser levados em consideração. Um outro aspecto extremamente relevante para os Estudos de Tradução continua sendo a análise dos paratextos disponíveis sobre determinada obra.

Assim, prefácios, introduções e notas do tradutor são peças muitas vezes fundamentais para se montar o panorama de referências sobre um trabalho, e nesses dados se pode verificar alguns dos aspectos citados acima, como o status determinado, seja do autor, da obra na cultura-fonte ou alvo, das línguas envolvidas ou mesmo do tradutor. O mesmo pode ser dito em relação aos valores, à ideologia, aos subtextos e aos intertextos implicados. Por sua vez, os metatextos, como as críticas e a tradição interpretativa, também servem com uma medida de como aquela obra é compreendida e revista em determinada literatura/cultura.

Pode parecer estranho, talvez incompleto, realizar um estudo de caráter comparatista acerca de práticas tão distantes (séculos XII, XIII e XVIII, XIX), mas este interesse é justificado, em parte, pelos exemplos significativos encontrados nestes períodos. Durante a pesquisa sobre a tradução na Espanha foi constatado que as épocas mencionadas apresentam rica produção tradutória. Além disso, na lacuna existente entre os dois grandes períodos abordados, que foi de quase 500 anos, esta atividade, apesar de existente, não revelou aspectos de real interesse para a presente pesquisa.

A idéia de relacionar alguns dos tópicos das análises de textos traduzidos que são relevantes e idéias teóricas tão inovadoras não serve apenas para demonstrar a "novidade" destas abordagens, como também para mostrar que hoje, assim como no passado, a questão do poder, da ideologia, do status etc. contribuem para que práticas tão antigas continuem em voga em outras nações também poderosas. Da mesma forma, esta relação também nos lembra que tal atividade de pasteurização persiste, não perdeu o poder de reavaliar culturas, domesticar textos e incluir identidades prevalentes.

Esta contraposição de épocas e estratégias tradutórias também pode servir para asseverar a importância da tradução para a compreensão da ideologia, assim como da patronagem envolvidas, sendo que apenas um dos motivos para tal consideração é que a tradução é um processo textual, ou seja, sua produção deixa marcas. Além disso, o argumento de que os Estudos de Tradução estão entrando em uma nova fase, na qual assumem novas posições teóricas resultantes de movimentos de diásporas e da globalização, não se sustenta quando recordamos, ao observar a empresa de tradução levada a cabo nos séculos XII e XIII, sem esquecer da Escuela de Bagdad ${ }^{7}$, que tomou forma séculos antes, que a interculturalidade é muito mais antiga. É ainda mais fácil de se perceber isso quando não se trata a questão dos Estudos Literários apenas do ponto de vista ocidental e etnocêntrico.

\section{REFERÊNCIAS BIBLIOGRÁFICAS}

ALVERNY, M. T. d'. "Les Traductions d'Aristote et de ses Commentateurs". Revue de Synthèse, III (49-52), Centre International de Synthèse, Albin Michel, 1982. p. 125-144.

BEAUjOUAN, G. "Fautes et Obscurités dans les Traductions Médicales du Moyen Âge". Revue de Synthèse, III (49-52), Centre International de Synthèse, Albin Michel, 1968. p. 145-152.

FERNÁNDEZ, E. P. Félix Maria de Samaniego, Adaptador de Cuentos Eróticos de La Fontaine. LAFARGA, F (ed.). La Traducción en España (1750-1830). Lengua, Literatura, Cultura. Lleida: Edicions de la Universitat de Lleida, 1999.

FOZ, C. El Traductor, la Iglesia y el Rey. Tradução de Enrique Folch, $1^{\text {a }}$ ed. Barcelona: 2000.

LAFARGA, F (ed.). La Traducción en España (1750-1830). Lengua, Literatura, Cultura. Lleida: Edicions de la Universitat de Lleida, 1999. 
LE GOFF, J. Le Travail dans les Systèmes de Valeur de l'Occident Médiéval. Le travail au Moyen Âge. Une approche interdisciplinaire, 1990. p. 7-21.

LEFEVERE, A. Translation, Rewriting, and the Manipulation of Literary Fame. Londres: Routledge, 1992.

NEWMARK, P. Approaches to Translation. Hempstead: Prentice Hall, 1981.

SOLALINDE, A. "Intervención de Alfonso X en la Redacción de sus Obras". Revista de Filología Española, 2, 1915. p.283-288.

TOURY, G. Translation, Literary Translation and Pseudotranslation. E. S. Shaffer (ed.) Comparative Criticism 6. Cambridge: Cambridge University Press, 1984. p. 73-85.

VENUTI, L. The Translator's Invisibility. Londres: Routledge, 1995.

VENUTI, L. The Scandals of Translation. Londres: Routledge, 1998.

Notas:

${ }^{2}$ Rei de Castilla, filho de Fernando el Santo. Sobre sua direção e participação direta, a famosa Escuela de Traductores de Toledo alcançou uma renovada glória intelectual por traduzir ao castelhano os conhecimentos mais importantes da cultura e civilização islâmicas. Entre as traduções realizadas que tiveram ampla divulgação em toda Europa se encontram Calila e Dimna, coleção de contos orientais derivados principalmente da coleção indiana Panchatantra, e também a Disciplina Clericalis, de Pedro Alfonso. O médico judeu Abraham el Alfaquín de Toledo traduziu o Libro de la Acafecha, de Azarquiel, o célebre astrônomo de Córdoba. Alfaquín também traduziu para o castelhano o Libro de la Escala de Mahoma.

${ }^{3}$ Trata-se de uma história universal em seis partes, formada principalmente por uma tradução do Antigo Testamento, à qual se adicionam algumas informações históricas sobre Roma, Grécia e Egito e que não foi concluída. Esta é a primeira obra sobre a história da Espanha e a segunda sobre a história universal. Este texto inicia um novo período da historiografia espanhola, pois é escrito, pela primeira vez, em língua castelhana e possui status de obra literária. Ele marca o nascimento da prosa escrita em romance.

${ }^{4}$ De acordo com Clara Foz (2000), em 1276 o Rei Alfonso X, “com la ayuda da Judá, uno de sus traductores, y de Samuel Leví, Juan de Mesina y Juan de Cremona, revisa el texto (Libro del Saber de Astronomía). Su trabajo consiste en suprimir los pasajes que le parecen superfluos o mal vertidos al castellano, en añadir algunos datos que juzga necesarios y en corrigir el estilo, com lo que crea, en suma, su propria versión” (p.73). Em outra passagem, Foz descreve mais um pouco da atividade do Rei em relação à tradução: "Samuel Leví (...) participa en la traducción-revisión del Libro de la Ochava Sphera, junto a otras cuatro personas, entre las que figura el mismo Rey" (p.77).

${ }^{5}$ Segundo Francisco Lafarga (1999) Aguilar Piñal propõe uma distribuição das traduções produzidas na Espanha do século XVIII e início do XIX que estabelece as seguintes porcentagens: dos títulos traduzidos, aproximadamente $65 \%$ procedem do francês, $23 \%$ do italiano, $7,3 \%$ do inglês, cerca de $3 \%$ do português e $1 \%$ do alemão.

${ }^{6}$ Francisco Lafarga (1999) comenta que: "En todo este proceso de cambio no está ausente una interferencia - doble interferencia - de Francia: por un lado, con la idea particular de la traducción conocida como belles infidèles, y por otro, con el tamiz de las versiones intermediarias francesas en las que tan a menudo llegaron los textos ingleses y alemanes en España (...) Etapa intermediaria no siempre confesada por el traductor - o por el editor - y que supone un grado más de dificultad" (p.15).

${ }^{7}$ Escuela de Bagdad: com a mudança da capital do mundo islâmico à cidade de Bagdá, se intensificou e sistematizou este exercício da tradução de textos filosóficos do grego ao árabe. O califa Al Mamún (813833), patrocinador do primeiro movimento filosófico relativamente "laicista" da historia do Islã, apoiou suas idéias com um programa de tradução de obras filosóficas gregas que foi levado a cabo na chamada "Casa de la Sabiduría" de Bagdá. 